\title{
COMPETITIVE ADVANTAGE MITRA KELUARGA HOSPITAL SURABAYA THROUGH DIFFERENTIATION AND EFFICIENCY
}

\author{
Adi Susanto \\ Widya Mandala Catholic University Surabaya \\ Adi-s@ukwms.ac.id
}

\section{A R T I C L E I N F O}

Article history:

Received : 10 March 2019

Revised : 25 March 2019

Accepted : 20 April 2019

Key words:

Differentiation strategies, efficiency

DOI:

https://doi.org/10.33508/rima.v2i1.2597

\begin{abstract}
A B S T R A C T
Growth and the high competition in the hospital business, demands the existence of an appropriate strategy to achieve competitive advantage. Strategies that can be used is a strategy of differentiation through efficiency and co-branding and green health care in building competitive advantage to achieve sustainable business growth. The strategy of differentiation can be made through product differentiation, service, human resources, product and image channels.

Differentiation strategy and the efficiency of performed detailed analysis using SWOT analysis, Resource Based View (RBV) and carried out in a comprehensive manner through the assessment method of the Balanced Scorecard (BSC), which measures the performance of companies from both the financial and non financial perspective as a whole, so that it can be produced more precise measurement of the indicators for the survival and growth of the company.

This thesis research done through qualitative approach on RS. Mitra Keluarga Surabaya on an ongoing basis to evaluate the strategy of differentiation and efficiency at the same time, to be able to always increase sales growth and get the value of an optimal efficiency in the operating costs of the hospital.
\end{abstract}

\section{INTRODUCTION}

Hospitals, as one of the health facilities, have a very strategic role in accelerating the improvement of community health status. Based on data from the Ministry of Health (Kemenkes), the number of data from hospitals in Indonesia has reached 2,601 (two thousand six hundred and one) units as of 2016. That number can increase in line with economic development. As of April 2018, information data recorded the number of hospitals in Indonesia reached 2,820 (two thousand eight hundred twenty) units, both for government and private hospitals.

The presence of hospitals in East Java Province alone amounted to 377 (three hundred seventy-seven) units in 2016, both general and specific. In Surabaya itself, based on the 2018 Surabaya Regional Development Work Plan (RKPD), the number of hospitals is 60 (sixty) units. One of them is the Surabaya Mitra Keluarga hospital which is part of the health care industry, which is taking part in receiving the fierce impact of hospital business competition, even though it has been 
accredited with the highest level of reaching the whole level in 2017, based on a decree from the Hospital Accreditation Commission (KARS) ) Indonesia, with the status of Plenary accredited, following KARS-SERT / 685 / IV / 2017.

The massive role of consumer demands and BPJS (Social Security Organizing Agency) health and labor, technological and service changes, and human resources and infrastructure require the right strategy to guide hospitals to achieve maximum results. Replacements through the development of financial technology, disruption, VUCA (volatility, uncertainty, complexity, and ambiguity), and regulation also make hospitals continue to grow and improve all aspects of the organization ranging from services, infrastructure, technology, products, product images, channels distribution, and human resources. The right strategy will significantly determine the hospital can achieve the goals to be made, namely a sustainable business.

Mitra Keluarga Surabaya Hospital has many excellent service facilities, such as the cardiac, brain and peripheral catheterization laboratories, brain, and spine center, MSCT 64 Slices, MRI HDxt 1.5 Tesla, breast ultrasound, mammography, bone densitometry, 4-dimensional ultrasound, laparoscopy, and endoscopy which needed by patients in improving the quality of their health. This hospital also provides supporting facilities, such as bank and ATM services, parking, emergency services, general poly, specialist poly, inpatient rooms ranging from SVIP class to class 3, individual ICU, ICCU, Intermediate, NICU, PICU, operating rooms, pharmaceutical installations, clinical laboratories, radiology equipped with MRI, CT Scan; hemodialysis, endoscopy, rehabilitation medic, medical check-up, ambulance and brain, and spine center. The right strategy is needed to deal with changes that bring about transformation due to the development of financial technology, disruption, and VUCA in the health business. At the writing of this research, the company's strategy is carried out through a differentiation strategy approach, efficiency through co-branding, and green health care as something unique. Environmentally friendly that can be used as a consideration of shareholders and other stakeholders to be able to achieve a competitive advantage in the service industry's health.

The purpose of research writing is to evaluate and analyze differentiation and efficiency strategies through co-branding and green health care for hospital companies in the face of increasingly competitive hospital industry developments, which can be beneficial for academic, corporate, and community development applications.

\section{LITERATURE REVIEW}

The competition strategy is an effort to find profitable competitive positions and aims to maintain the areas and forces that determine the company's location in business competition. This strategy will describe the direction of the business that follows the chosen environment and is a guideline for allocating the resources and efforts of an organization.

The Porter Five Forces Strategy in business competition as a model developed by Michael Porter (1979) to describe the framework as an analysis of business development. This business strategy has seen from the five strengths in a company by involving relationships between competitors in the industry, potential competitors, suppliers, buyers, and alternative solutions to the existing competition problems.

The Resource-Based View strategy developed by Jay Barney (1991) has a vital role for strategic management, stating that 
organizations will achieve sustained competitive advantage if they have valuable, unique, rare, and difficult to imitate resources. The resource-based view emphasizes the internal factors of the organization, and the organization can determine the strategy to be carried out following the organization's capabilities. Resource-based view strategy and Porter's 5 Forces combined, it will get a more complete business strategy. This is because the resource-based view sees the company from an internal perspective, while Porter's 5 Forces sees the company from an external perspective. Resource-based views fundamentally state that valuable, rare, or unique resources are difficult to replicate, and no substitute can create a competitive advantage for companies with the underlying assumption of heterogeneity and immobility of these resources.

The business strategy used will be evaluated by the SWOT analysis and the Balanced Scorecard (BSC). The SWOT analysis carries out the identification of internal factors (strengths and weaknesses) and external factors (opportunities and threats) of the organization in a systematic way to formulate organizational strategies. Balanced Scorecard (BSC) as a tool for mapping strategy (strategy mapping) and performance management (performance management tools) that can help organizations to translate vision, strategy into action by utilizing a set of financial and non-financial indicators that are all intertwined in a causal relationship, and Finally, a strategic and appropriate plan can be arranged according to the company's needs, through four perspectives consisting of learning and growth perspective, internal business process perspective, consumer perspective, and financial perspective.

The differentiation strategy will increase the competitive advantage obtained by creating a difference (different) between the company's products with competitors' products. This strategy can expand the business by establishing a new company or adding new products or services based on the types. In the end, it will find the company's uniqueness that makes it different from its competitors.

A co-branding is a form of cooperation between two or more brands that already have significant recognition from consumers. It is an effective way to develop brands, strengthen brands, and provide mutual benefits.

Green health care was born from the concept of green buildings or green buildings applied to health service installations, in general, hospitals. This concept combines development that does not damage the environment with health services that also does not pollute the surrounding environment. The principle of green health care is to look for ways to prevent environmental damage that impacts health services and provide excellent quality health services. One of the principles of green health care is the minimum harmful waste that is less waste that is proven to be able to reduce the amount of waste produced by a health facility.

Industry analysis through the five forces developed by Michael Porter and the resource-based view developed by Jay Barney are two sides to one coin. Also, complementary between the two approaches is very logical when viewed from the SWOT concept (strengths, weaknesses, opportunities, and breathing). The idea of technical analysis through five forces is used to analyze opportunities and threats. In contrast, the concept of a resource-based view is used to analyze the company's strengths and weaknesses.

Both approaches are likely to complement each other because they both discuss the same phenomenon, namely, sustainable competitive advantage and the corresponding analysis level. The two 
perspectives have differences, but the similarities in their focus on achieving sustainable competitive advantage and both aspects are equally likely to lead to performance above ordinary. There is an opportunity to integrate the two approaches to make sustainable competitive advantage (sustainable business growth) and similarly pay attention to company resources better than having to contradict each other continually. Secondly, we can measure the five forces and resource-based view by assessing through SWOT analysis, which explains the company's strengths and opportunities and also understands the weaknesses and threats of a business in achieving a competitive advantage. In the current and future business competition. Furthermore, the measurement in an integrated and comprehensive manner can be carried out with a balanced scorecard (BSC) approach that aligns the balance and analysis both in terms of financial and nonfinancial perspectives. The company's view will be measured not only through a financial perspective but also through a customer perspective, learning and growth perspective, and internal business process perspective, with the aim that the company can still compete in the existing market.

\section{METHODOLOGY}

The research approach undertaken by researchers in this paper is research with a qualitative approach, with one of the variables being an intensive case study. Existing data in the writing of this research will be arranged descriptively, without hypotheses given in this study, and data obtained from discourse analysis from hospital executives, case studies, and literature sources. The strategy of differentiation, efficiency through cobranding and green health care to achieve competitive advantage in Mitra Keluarga Surabaya hospital is processed with a SWOT analysis, equipped with a resource- based view and balanced scorecard to implement differentiation and efficiency strategies through co-branding and green health care in building a competitive advantage in the Mitra Keluarga Surabaya hospital.

\section{RESULT}

Differentiation Strategy of Mitra Keluarga Hospital in Surabaya

To always build and improve hospitals' competitiveness (competitive advantage), the Mitra Mitra Surabaya hospital carries out operational and strategic activities through a differentiation strategy. The differentiation strategy is carried out as an actual activity of the company to maintain and increase the value of the company's product sales and provide health services to the people of Surabaya and its surroundings.

The differentiation strategy is carried out by creating differences between hospital products and competing products. This strategy can expand the hospital business by adding new and different products and services, which will find the hospital's uniqueness that makes it different from other hospitals that are competitors. This strategy is unique and is expected to provide added value to the products and services that are sold or provided to consumers or the public. A functional differentiation will give a very positive value in the survival, growth, and development of the hospital, both in the short and long term. The differentiation strategy was undertaken by Mitra Keluarga Surabaya hospital, among others: differentiation of products, services, human resources, channels, and product images.

Efficiency Strategy through Co-branding and Green Health Care

Co-branding has been carried out by the Mitra Keluarga Surabaya hospital, among others: Co-branding and Mandiri 
Inhealth, Gojek - Halo Doc service, and BPJS Labor (BPJS TK). To improve the Mitra Keluarga Surabaya hospital's efficiency strategy, it is carried out through company activities that are considered to go green and are proven to reduce unnecessary waste of operational costs. Green health care activities undertaken by Mitra Keluarga Surabaya Hospital are as follows: reducing and minimizing the use of film and plastic in the results of diagnosis of health services, one billing system (online), and waste treatment.

SWOT Analysis of Mitra Keluarga Surabaya Hospital

Seeing the strength of the Mitra Keluarga Surabaya hospital in providing health services, it is a comprehensive class B hospital, large, sophisticated equipment, SAP system, and value-added efficiency cobranding. It remains environmentally friendly in health services to patients and families. Reducing the presence of weaknesses and threats by paying attention to opportunities for the advancement of competitive hospitals, the strategy suitable for Mitra Mitra Surabaya hospitals today is the SO (Strength and Opportunity) strategy. The approach adopted in this condition is to support a progressive growth policy. It is used to capture and take advantage of existing industry opportunities by maximizing internal strength. This strategy uses the internal forces of Mitra Keluarga Surabaya hospitals to take advantage of external opportunities. In this SO quadrant, it can be stated that it supports a progressive strategy by developing existing strengths and increasing and maintaining existing opportunities.

Analysis of RBV (Resource Based View) of the $\underline{R S . S u r a b a y a \text { Family Partners }}$

These strengths are identified from the hospital's resources using the RBV (Resource Based View) model to more easily determine the strengths in exploiting opportunities. Not to forget also minimize the existing weaknesses and face threats or change into opportunities that exist.

Assessment through the RS Balanced Scorecard. Surabaya Family Partners

Measurement of the value of Mitra Keluarga Surabaya Hospital by measuring through the balanced scorecard, are: financial perspective, during the last 5 (five) years (2012-2017) cumulative sales growth (revenue growth) was 26.27\%, and collective earnings growth net (net income) is $30.08 \%$. Customer perspective is seen from the value of customer satisfaction, both inpatients and outpatients, for health services in the Mitra Keluarga Surabaya hospital, on average in the last 3 (three) years satisfaction values above $90 \%$ (above ninety percent). Learning and growth perspective, Mitra Mitra Surabaya Hospital strives to improve the ability of human resources by providing mandatory training or training to all levels of employees, at least 3 (three) hours of training per month, including at the executive level. Internal business process perspective transforms the business world by implementing SAP (Systems, Applications \& Products in Data Processing) systems to improve control and quality of health services for patients and their families.

Achievement Results of Mitra Keluarga Hospital in Surabaya

The differentiation and efficiency strategy through co-branding and green health care carried out by Mitra Keluarga Surabaya hospital to build competitive advantage and is expected to achieve sustainable business growth, has provided very positive, valuable and quality value to the hospital. Seen from 2012 - 2017, the number of sales increased, growing by $26.27 \%$, and the number of costs was more efficient, so the average profit value was 
$30.08 \%$ to equity holders. The hospital is also accredited with a whole level, sustainable development.

\section{CONCLUSION}

Mitra Keluarga Surabaya Hospital has a differentiation strategy from products, services, human resources, channels, and product images. Efficiency through cobranding and green health care. Cobranding works well with partners such as Mandiri Inhealth, Gojek, through halo dok services, and BPJS TK, which can make a positive contribution to efficiency, which is to reduce the company's operational costs. Green health care itself has also contributed to added value to customers and the community, an increase in health services, and even a reduction in hospital costs, and continued attention to a comfortable and clean environment.

Differentiation and efficiency strategies through co-branding and green health care have been used by Mitra Keluarga Surabaya hospitals based on SWOT analysis (strength, weakness, opportunity, threat). Resource Based Value (RBV), and comprehensive assessment through the Balanced Scorecard (BSC) ) has been able to build competitive advantage, and can achieve sustainable business growth.

\section{$\underline{\text { Suggestion }}$}

Considering Mitra Keluarga, hospitals receive BPJS (Social Security Organizing Agency) membership or immediately open a new hospital that can accept the BPJS Health program. The efficiency strategy through co-branding and green health care can be improved by opening opportunities for cooperation with companies and insurance in a mutually beneficial manner and increasing the processing of medical waste itself by using autoclave technology.

\section{REFERENCES}

Abdussamad, Z. (2013) Pengaruh Diferensiasi Jasa dan Kualitas Pelayanan Terhadap Kepuasan Pasien pada Rumah Sakit Islam Gorontalo. Gorontalo.

Aditama, Tjandra Yoga.(2003) Manajemen Rumah Sakit, Edisi Kedua. UI Press. Jakarta.

Barney, Jay. (1986). “Organizational Culture: Can It Be a Source of Sustained Competitive Advantage?" Academy of Manajement Review.

Barney, Jay. (1991). "Firm Resource and Sustained Competitive Advantage", Journal of Management.

Bartlett Christopher A, Beamish Paul W. (2014). Transnational Management Seventh Edition. Singapura : Mc Graw Hill Education.

B. Balaji. (2006). Services Marketing and Management S. Chand \& Co. New Delhi: Company Private limited.

Boone, Louis E., and David L. Kurtz. (2006). Contemporary Marketing. Thomson South-Western.

Chan Kim,W \& Mauborgne, R. (2006). Blue Ocean Strategy (terjemahan) Wahono, S. Erlangga. Jakarta

Chuan-Biau Chen, Pi-Lien Kao.(2011). The Effects of the Hospital Marketing Promotion on Consumers' Choice of Hospitals Consumers. The Journal of Human Resource and Adult Learning Vol. 7, Num. 2, Taiwan.

Cooper Donals R, Schindler Pamela S. (2003). Bussines Research Methods Eight 
Edition. Singapura : International Edition.

David, Fred R. (2006). Strategic Management Seventh Edition. New Jersey: Prentice Hall International Inc.

Duncan, W.Jack. (1996). Strategic Management of Health Care Organization Second Edition. Massachuset : Blackwell Publisher Inc. Cambridge.

Hunger, David, Wheelen. (1996). Strategic Management Fifth Edition. USA: Wesley Publishing Company, Inc.

Johnson Gerry, Scholes Kevan, Whittington Richard. (2008), Exploring Corporate Strategy. Eight Edition, England : Prentice Hall

Keputusan Menteri Kesehatan Republik Indonesia Nomor HK.02.02/MENKES/52/2015. 6 Februari 2015. Tentang Rencana Strategis Kementerian Kesehatan tahun 2015-2019. Kemenkes RI Press. Jakarta.

Kotler, Philip, Kevin Lane Keller. (2009). Manajemen Pemasaran Edisi 13 Jilid 1. Erlangga. Jakarta.

Lamb, Hair, Mc Daniel. (2001). Pemasaran $B u k u$ 1. Penerbit Salemba Empat, Jakarta.

Lourensius L. T , Nerys. (2014). Co-Branding Salah Satu Alternatif Strategi Rumah Sakit Dalam Menghadapi Persaingan. Yogyakarta: JBMA - Vol. II, No. 2.

Orsato Renato J. (2009). Sustainability Strategies: When Does it Pay to Be Green ? UK : Palgrave Macmillan

Pearce II, John.A and Richard B. Robinson. (2009).

Strategic
ManagementFormulation, Implementation and Control. USA: Mc Graw-Hill International Edition.

Porter, Michael E. (1985). Competitive Advantage : Creating and Sustaining Superior Performance. New York, United States of America : The Free Press Edition.

Porter, Michael E.(1980). Competitive Strategy : Techniques for Analyzing Industries and Competitors. New York, United States of America : The Free Press Edition.

Rangkuti, Freddy. (2010). Analisis SWOT Teknik Membedah Kasus Bisnis. PT. Gramedia Pustaka Utama Jakarta

Raharjo, ST. (2007). Informasi, Orientasi Pasar, dan Implementasi Strategi Diferensiasi Terhadap Kualitas Layanan Dalam Mencapai Keunggulan Bersaing (Studi Kasus Pada Rumah Sakit Islam Sultan Agung Semarang.Semarang.

Ries, Al, and Jack Trout. (2001). Positioning: The Battle for Your Mind 20th Anniversary Edition. USA: McGrawHill.

Trisnantoro, Laksono. (2015). Aspek Strategis Manajemen Rumah Sakit. Penerbit Andi Yogyakarta.

Yazit. (2001). Manajemen Strategik Pengantar Proses Berpikir Strategik. Binarupa Aksara Jakarta. 